\title{
Aplikasi Metode Geolistrik dan Analisis \\ $X$-Ray Diffraction (XRD) untuk Investigasi Longsor di Pidada, Kecamatan Panjang, Bandar Lampung
}

\section{Applications of Geoelectrical Methods and \\ X-Ray Diffraction (XRD) Analysis for Landslide Investigations in Pidada, Panjang District, Bandar Lampung}

\author{
Rahmi Mulyasari $^{1 *}$, Suharno ${ }^{1}$, Nandi Haerudin ${ }^{1}$, Hesti $^{1}$, Akroma Hidayatika1, \\ Ida Bagus Suananda Yogi ${ }^{1}$, Sugeng Purwo Saputro ${ }^{2}$ \\ ${ }^{1}$ Universitas Lampung, Jl. Prof. Dr. Ir. Sumantri Brojonegoro, Bandar Lampung 35141, Indonesia \\ ${ }^{2}$ Badan Riset dan Inovasi Nasional (BRIN), Jl. Sangkuriang, Bandung, 40135, Indonesia \\ *E-mail: rahmi.mulyasari@eng.unila.ac.id
}

Naskah diterima: 27 April 2021, direvisi: 31 Agustus 2021, disetujui: 29 Oktober 2021

DOI: 10.17146/eksplorium.2021.42.2.6304

\begin{abstract}
ABSTRAK
Bandar Lampung merupakan wilayah perkotaan padat penduduk yang terdiri atas daratan dan perairan dengan beberapa dataran tinggi dan pegunungan yang terbentang di wilayah ini. Untuk mendukung pembangunan yang berkelanjutan di sebuah kawasan kota diperlukan konsep penataan wilayah yang mempertimbangkan segala aspek, salah satunya adalah aspek potensi bencana. Salah satu bencana yang berpotensi terjadi di Bandar Lampung, khususnya di Kecamatan Panjang, adalah gerakan massa/longsoran. Berdasarkan penelitian sebelumnya, daerah ini terekam memiliki beberapa titik sejarah longsor tetapi belum ada mitigasi/penanggulangan yang diaplikasikan khusus untuk jenis bencana tersebut. Tujuan dari penelitian ini adalah untuk mengetahui susunan batuan yang berada pada zona rawan longsor Kecamatan Panjang menggunakan metode geolistrik resistivitas serta untuk mengetahui hasil penilaian keteknikan tanah yang diperoleh dari hasil analisis litologi menggunakan X-Ray Diffraction (XRD). Hasil analisis dua lintasan geolistrik mengindikasikan adanya tiga lapisan litologi pada daerah penelitian, yaitu sedimen tuf dengan nilai resistivitas dan kedalaman antara (1-40 $\Omega \mathrm{m} ; 0,4-4 \mathrm{~m})$, zona kontak atau bidang gelincir (40-120 $\Omega \mathrm{m} ; 2-4 \mathrm{~m}$ ), dan breksi padu dengan komponen batuan beku (> $120 \Omega \mathrm{m} ; 2-22 \mathrm{~m}$ ). Selanjutnya berdasarkan hasil analisis penilaian keteknikan tanah, sedimen tuf sebagai lapisan permukaan yang mengalami longsoran diidentifikasi memiliki sifat keteknikan litologi yang rentan karena telah mengalami oksidasi dan pelapukan yang cukup intensif. Data yang diperoleh ini diharapkan dapat dimanfaatkan sebagai data dukung penataan wilayah berbasis potensi bencana.
\end{abstract}

Kata kunci: Bandar Lampung, bencana, longsor, geolistrik, X-Ray Diffraction.

\begin{abstract}
Bandar Lampung is a densely populated urban area consisting of land and water with several plateaus and mountains that stretch across this region. To support sustainable development in a city area, it is necessary to have a regional arrangement concept that considers all aspects, one of which is the potential disaster aspect. One of the potential disasters in Bandar Lampung, especially in Panjang District is a mass movement/landslide. Based on previous research, this area has been recorded as having several historical points of landslides, but there is no mitigation/response specifically for this type of disaster. The purpose of this study was to determine the arrangement of rocks that are in the landslide-prone zone in Panjang District using the geoelectric resistivity method and to analyze the soil engineering assessment obtained from the results of lithological analysis using X-Ray Diffraction $(X R D)$. The results of the geoelectric analysis indicate that there are three lithological layers in the study area;

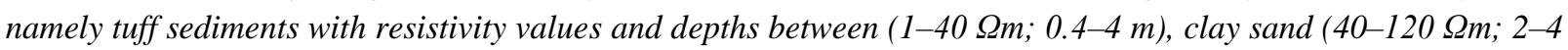


$m)$, and solid breccias with igneous rock components (>120 $\Omega m ; 2-22 \mathrm{~m}$ ). Furthermore, based on the results of the analysis of soil engineering assessments, tuff sediment as a surface layer that has experienced landslides has been identified as having susceptible lithological engineering properties because it has undergone quite intensive oxidation and weathering. The data obtained is expected to be used as supporting data for disaster potential-based regional planning.

Keywords: Bandar Lampung, disaster, landslides, geoelectricity, X-Ray Diffraction.

\section{PENDAHULUAN}

Longsoran atau gerakan massa merupakan suatu peristiwa geologi berupa perpindahan massa tanah hingga batuan yang disebabkan oleh gaya gravitasi bumi [1]. Longsor merupakan bencana yang terjadi karena dipengaruhi oleh faktor morfologi dan kemiringan lereng, litologi batuan, penggunaan lahan [2], struktur geologi [3], serta hidrogeologi [4]. Longsor dapat terjadi ketika gaya pendorong lebih besar dibandingkan dengan gaya penahan pada lereng [5]. Gaya pendorong dipengaruhi oleh kemiringan lereng, kandungan air, dan beban tanah sedangkan gaya penahan dipengaruhi oleh kepadatan dan kekuatan tanah.

Badan Nasional Penanggulangan Bencana (BNPB) mencatat bahwa longsor merupakan salah satu bencana yang paling banyak menelan korban dengan frekuensi kejadian yang terus meningkat setiap tahunnya [6]. Sekitar 179 kabupaten merupakan lokasi rawan bencana longsor di Indonesia, termasuk di dalamnya Bandar Lampung yang memiliki kelas risiko tinggi dan menempati peringkat 18 se-Indonesia [7].

Bandar Lampung secara geografis terletak pada $5^{\circ} 20^{\prime}-5^{\circ} 30^{\prime}$ LS dan $105^{\circ} 28^{\prime}-105^{\circ} 37^{\prime}$ BT. Kota ini merupakan wilayah perkotaan padat penduduk yang berada pada fisiografi Bukit Barisan. Berdasarkan morfologinya, Bandar Lampung termasuk ke dalam morfologi daerah pantai berbukit sampai datar [8]. Kondisi geologi di Bandar Lampung dipengaruhi oleh sesar/patahan yang salah satunya adalah Sesar Lampung-Panjang yang berarah NW-SE [9]. Beberapa patahan terlihat jelas melintasi Bandar Lampung. Keberadaan patahan tersebut tercermin pada kondisi morfologinya yang berupa perbukitan dengan kelerengan yang curam [10].

Berdasarkan stratigrafi regional, daerah penelitian termasuk ke dalam batuan produk gunung api Formasi Tarahan (Tpot) yang berupa tuf padu, breksi dengan sisipan rijang; Formasi Campang (Tpoc) bagian bawah yang terdiri dari perselingan batulempung, serpih, dan tuf padu, serta bagian atas yang terdiri dari breksi aneka bahan dengan sisipan batupasir dan batulanau; dan Sekis Way Galih (Pzgs) yang terdiri dari sekis amfibolit hijau dan amfibolit ortogenes dioritan [9]. Kondisi geologi yang demikian dan ditambah dengan tingkat curah hujan yang tinggi menyebabkan daerah tersebut rentan terjadinya longsoran [2],[4].

Kecamatan Panjang memiliki potensi gerakan tanah menengah-tinggi [11]. Oleh karena itu, penting untuk melakukan penataan wilayah di area potensi longsor di Kecamatan Panjang. Penelitian pendahuluan mengenai penataan gerakan massa/longsor di daerah ini telah dilakukan pada tahun 2018 dengan pembuatan peta geomorfologi untuk rekomendasi pengembangan wilayah [10]. Berdasarkan penelitian tersebut, Kecamatan Panjang termasuk pada tingkat potensi bahaya yang tinggi terkait kondisi geomofologi dan sesar yang mengontrolnya. Selain itu, telah dilakukan pula pemetaan zonasi area potensi 
gerakan massa di sepanjang Sesar LampungPanjang, Bandar Lampung. Berdasarkan penelitian tersebut, wilayah di sepanjang Sesar Lampung-Panjang diketahui berada pada zona potensi gerakan massa sedang-tinggi. Bencana longsor yang belum ada penanggulangan khususnya terekam pernah beberapa kali terjadi pada beberapa titik di Kecamatan Panjang [12].

Berdasarkan beberapa hasil penelitian tersebut, litologi daerah yang mengalami longsoran ini perlu diteliti lebih lanjut. Analisis mineral dapat digunakan untuk penilaian keteknikan batuan/tanah [13]. Penilaian ini menambah informasi dalam penataan suatu wilayah. Salah satu teknik analisis yang dapat dimanfaatkan untuk mengetahui penilaian keteknikan batuan/tanah adalah dengan X-Ray Diffraction (XRD).

Penelitian ini bertujuan untuk memperoleh data dukung penataan wilayah berbasis potensi bencana. Adapun metode pengumpulan data yang digunakan adalah metode geolistrik resistivitas untuk menentukan litologi bawah permukaan dan analisis XRD untuk menentukan karakteristik mineral pemicu longsoran.

\section{METODOLOGI}

Penelitian ini dilakukan di Kecamatan Panjang, Bandar Lampung. Metode yang digunakan pada penelitian ini adalah metode geolistrik resistivitas dan analisis XRD. Secara lebih rinci, prosedur penelitian dibagi menjadi empat tahap. Tahap pertama pada penelitian ini adalah melakukan studi pustaka untuk mendapatkan data penunjang penelitian, terutama mengenai geologi daerah penelitian, baik secara regional maupun lokal. Data penunjang lain yang dipelajari adalah peta topografi citra ALOS PALSAR DEM [14], peta tata guna lahan [15], peta curah hujan [12], peta geomorfologi [10], peta zonasi potensi area gerakan massa/longsor, dan data sejarah longsor di zona rawan longsor Kecamatan Panjang [12].

Tahap kedua adalah melakukan survei pendahuluan untuk mengetahui gambaran umum dan menggali informasi di lokasi penelitian, seperti topografi dan lokasi perumahan penduduk. Tahap ini dilakukan untuk membuat desain survei di lokasi penelitian terkait penentuan arah dan panjang lintasan untuk pengukuran geolistrik resistivitas.

Tahap ketiga adalah melakukan pengukuran geolistrik resistivitas 2D. Pada penelitian ini digunakan konfigurasi WennerSchlumberger yang merupakan gabungan antara pengukuran resistivity mapping (penentuan sebaran lapisan tanah secara horizontal) menggunakan konfigurasi Wenner dan resistivity sounding (penentuan sebaran konduktivitas batuan secara vertikal) menggunakan konfigurasi Schlumberger. Jika dibandingkan dengan konfigurasi Wenner, konfigurasi Schlumberger mempunyai kedalaman penetrasi 10\% lebih besar [16]. Ilustrasi titik-titik pengukurannya ditunjukkan pada Gambar 1. Pengukuran ini menggunakan alat Naniura NRD-300 dan GF Instrumen ARES 3000. Langkah pertama dalam pengukuran geolistrik resistivitas adalah menentukan posisi sentral ( 0 meter) sebagai titik awal pengukuran dan koordinatnya dicatat menggunakan GPS. Langkah berikutnya yaitu membentangkan meteran untuk menentukan letak dan spasi dari masingmasing elektroda sehingga selanjutnya dapat dilakukan pemasangan elektroda dan kabel elektroda. Pemasangan elektroda arus (C1 dan C2) dan elektroda tegangan (P1 dan P2) sesuai dengan konfigurasi Wenner-Schlumberger. Elektroda arus dan elektroda potensial dihubungkan dengan alat resistivitimeter. Selanjutnya, arus diinjeksikan ke dalam bumi 
melalui elektroda arus. Langkah terakhir adalah mencatat besarnya nilai kuat arus (I) dan beda potensial $(\Delta \mathrm{V})$ yang terukur pada resistivitimeter. Pengukuran dilakukan pada satu lintasan dengan panjang masing-masing lintasan sekitar $100 \mathrm{~m}$.

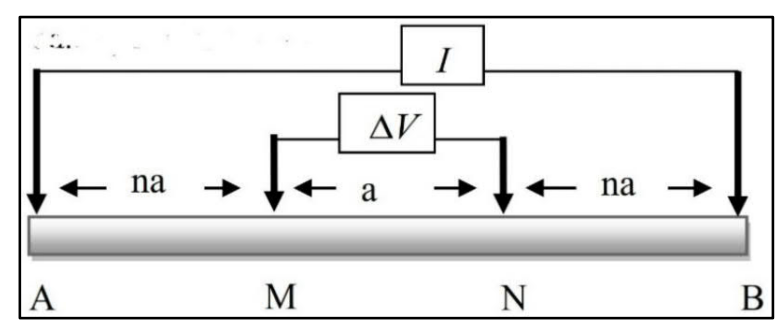

Gambar 1. Ilustrasi titik-titik pengukuran konfigurasi Wenner-Schlumberger [17].

Tahap keempat adalah melakukan pengolahan data geolistrik resistivitas. Data diambil dengan menggunakan resistivitimeter yang kemudian diunduh dan diproses menggunakan komputer. Data tersebut berupa informasi tanggal dan waktu pengambilan data, $\Delta \mathrm{V}$, I, posisi elektroda arus (C1 dan $\mathrm{C} 2)$, serta posisi elektroda potensial (P1 dan P2). Data ini selanjutnya diolah menggunakan perangkat lunak Microsoft Excel untuk mendapatkan nilai resistivitas semu ( $\rho$ semu). Kemudian proses inversi dilakukan menggunakan perangkat lunak Res2Dinv sehingga akhirnya diperoleh model penampang resistivitas yang memiliki elevasi (topografi). Lapisan struktur bawah permukaannya dapat diketahui berdasarkan hasil distribusi nilai resistivitas dalam penampang 2D.

Tahap kelima adalah pengambilan sampel batuan dan analisis XRD. Pada tahap ini dilakukan karakterisasi mineral dengan metode difraksi sinar X (XRD). Sampel yang diambil adalah sampel batuan yang berada di sekitar daerah pengukuran geolistrik resistivitas. Proses pengambilan sampel dilakukan pada permukaan. Sampel batuan diidentifikasi secara makro yang meliputi jenis, warna, tekstur, struktur, dan kekerasan. Sampel yang diperoleh dibawa ke Laboratorium Balai Penelitian Teknologi Mineral-LIPI, Lampung Selatan untuk dilakukan analisis XRD. Hasil analisis XRD digunakan sebagai pertimbangan analisis terpadu, interpretasi, dan rekomendasi.

Tahap keenam adalah analisis dan interpretasi data. Data yang telah diperoleh kemudian dianalisis dan diinterpretasi untuk mendapatkan hasil yang sesuai. Pada tahap ini, interpretasi data hasil pengolahan geolistrik resistivitas dikorelasikan dengan peta topografi, peta geologi, serta tabel nilai resistivitas batuan. Data sampel batuan yang telah dianalisis dengan metode XRD digunakan sebagai pendukung hasil interpretasi data. Hasil dari proses ini adalah didapatkannya model bawah permukaan dari lapisan lereng daerah penelitian. Data XRD juga memberikan tambahan informasi berupa sifat batuan dan tanah berdasarkan kandungan mineral batuan tersebut. Indikasi perkiraan bentuk lapisan tanah dan batuan di lereng serta sifat dan potensi penyebab longsor didapatkan pada akhir penelitian ini.

\section{HASIL DAN PEMBAHASAN}

Temuan signifikan dari penelitian ini adalah model bawah permukaan lapisan lereng daerah rawan longsor serta sifat keteknikan batuan yang mengalami longsoran. Berdasarkan studi pustaka dan sejarah kejadian longsor, titik pengukuran yang dipilih berada di Jalan Suban, Kelurahan Pidada, Kecamatan Panjang, Bandar Lampung, yang mengalami longsor pada bulan Januari 2020. Longsoran tersebut menyebabkan tanah di wilayah perbukitan turun dan menutup akses Jalan Suban. 
Hasil survei pendahuluan pada lokasi penelitian menunjukkan kondisi morfologi yang berupa perbukitan dengan kemiringan lereng $>30^{\circ}$ dan elevasi 20-150 mdpl. Berdasarkan pengamatan geologi, daerah penelitian tersusun oleh litologi permukaan berupa tuf yang telah mengalami pelapukan. Berdasarkan hasil pengamatan, satu titik lokasi pengukuran dipilih di tepi Jalan Suban (Gambar 2).

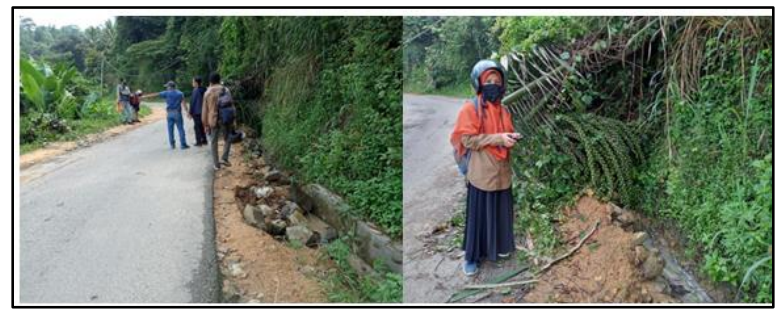

Gambar 2. Titik lokasi pengukuran geolistrik.

\section{Hasil Pengukuran Geolistrik Resistivitas}

Pengambilan data 2D pada penelitian ini dilakukan pada dua lintasan survei resistivitas. Panjang lintasan $\mathrm{AB}$ pengukuran daerah penelitian adalah $44 \mathrm{~m}$ dengan jarak per titiknya adalah $2 \mathrm{~m}$. Akuisisi data resistivitas pada lintasan $\mathrm{AB}$, yaitu titik 0 pada 535788 dan 9396371 dengan elevasi 74 mdpl serta titik 23 pada 535796 dan 9396338 dengan elevasi 69 mdpl. Lintasan AB diambil tepat di lokasi longsoran dengan arah bentangan ke arah utara-selatan. Sementara itu, lintasan CD memiliki panjang lintasan $110 \mathrm{~m}$ dengan jarak tiap elektroda $5 \mathrm{~m}$. Titik 0 berada pada elevasi 65 mdpl dan titik ke-23 berada pada elevasi 103 mdpl. Peta pengukuran tersebut disajikan pada Gambar 3 dan visualisasi daerah penelitian disajikan pada Gambar 4.

Pengukuran geolistrik dilakukan dengan metode resistivitas konfigurasi WennerSchlumberger pada dua lintasan. Panjang lintasan $\mathrm{AB}$ pada pengukuran yang dilakukan adalah 44 meter dan lintasan CD sepanjang 110 meter. Data hasil pengukuran kemudian diinversi dengan menggunakan perangkat lunak Res2Dinv untuk memeroleh penampang 2D. Penampang 2D hasil inversi memberikan informasi mengenai distribusi nilai resistivitas batuan di bawah permukaan pada setiap lintasan pengukuran. Tampilan 2D dari data hasil inversi lintasan $\mathrm{AB}$ tanpa topografi dengan menggunakan perangkat lunak Res2Dinv dapat dilihat pada Gambar 5.

Hasil inversi lintasan $\mathrm{AB}$ dan $\mathrm{CD}$ dengan topografi dapat dilihat pada Gambar 6 dan Gambar 7. Hal yang perlu diperhatikan adalah skala gambar pada Gambar 6 dan 7 berbeda. Lintasan AB pada Gambar 6 memiliki panjang $44 \mathrm{~m}$ dan kedalaman $6 \mathrm{~m}$ sementara lintasan CD pada Gambar 7 memiliki panjang $110 \mathrm{~m}$ dengan kedalaman $22 \mathrm{~m}$.

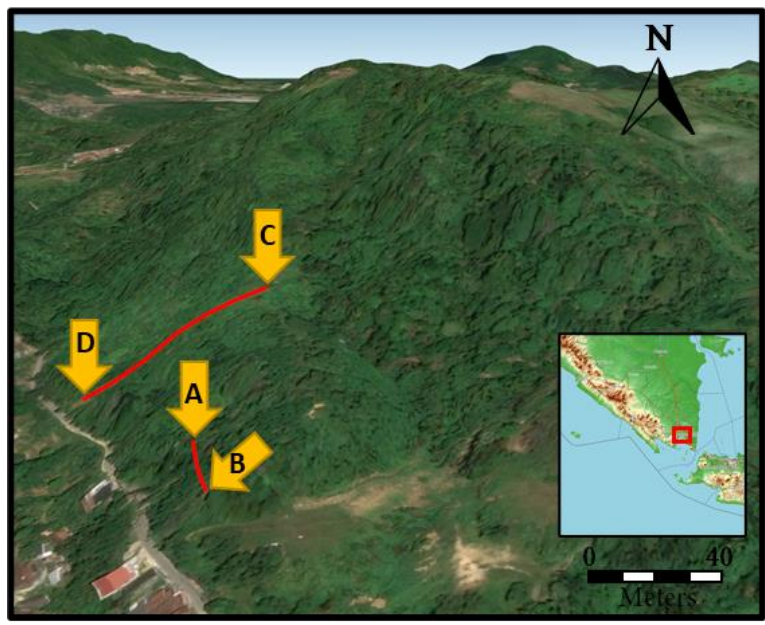

Gambar 3. Peta pengukuran 2D geolistrik Kecamatan Panjang.

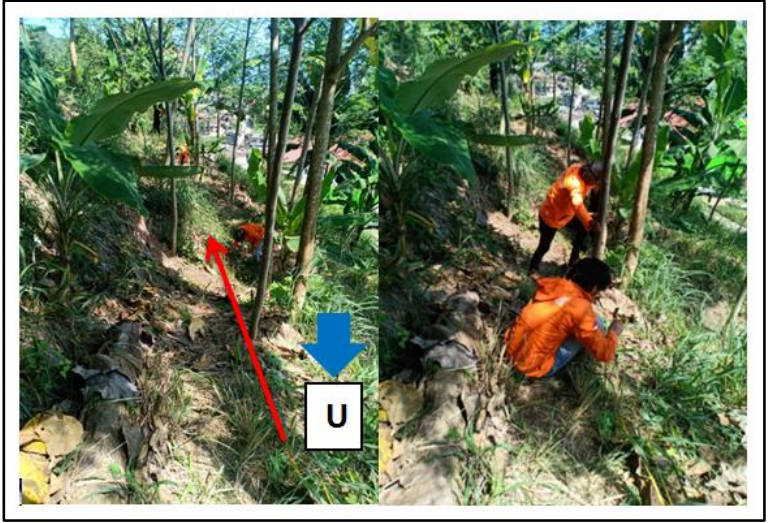

Gambar 4. Visualiasi daerah penelitian lintasan AB. 


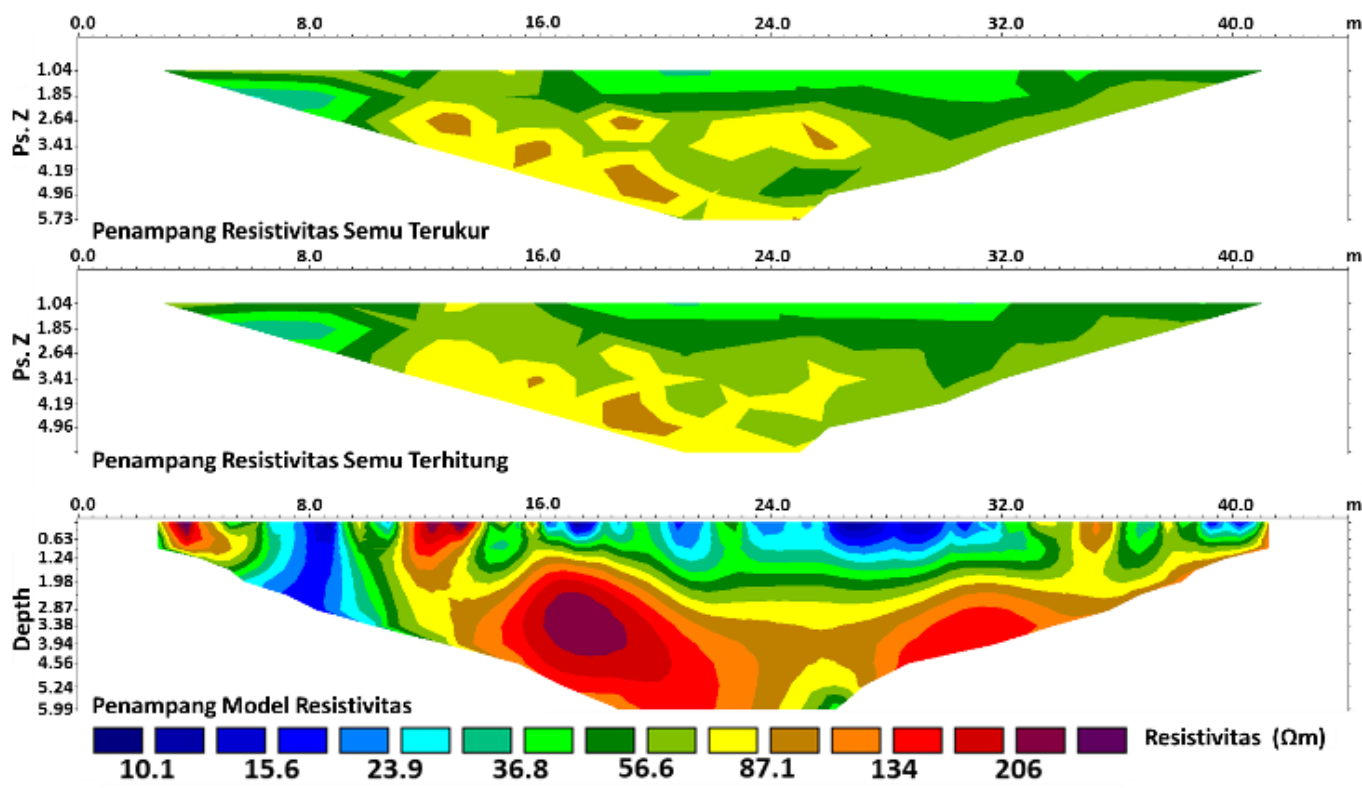

Gambar 5. Penampang 2D lintasan AB hasil inversi tanpa topografi.

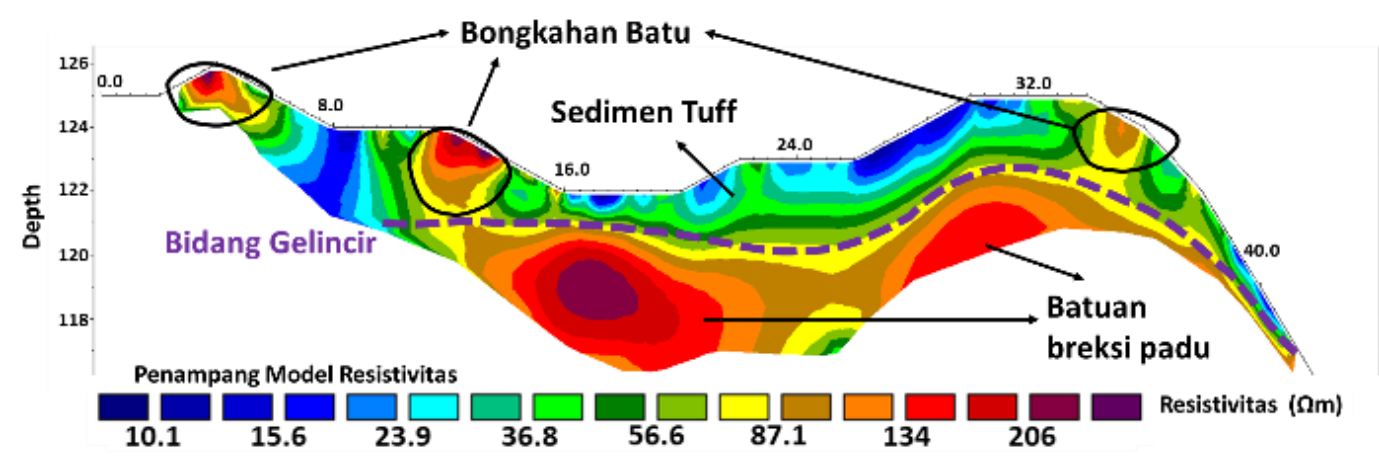

Gambar 6. Penampang AB hasil inversi dengan topografi.

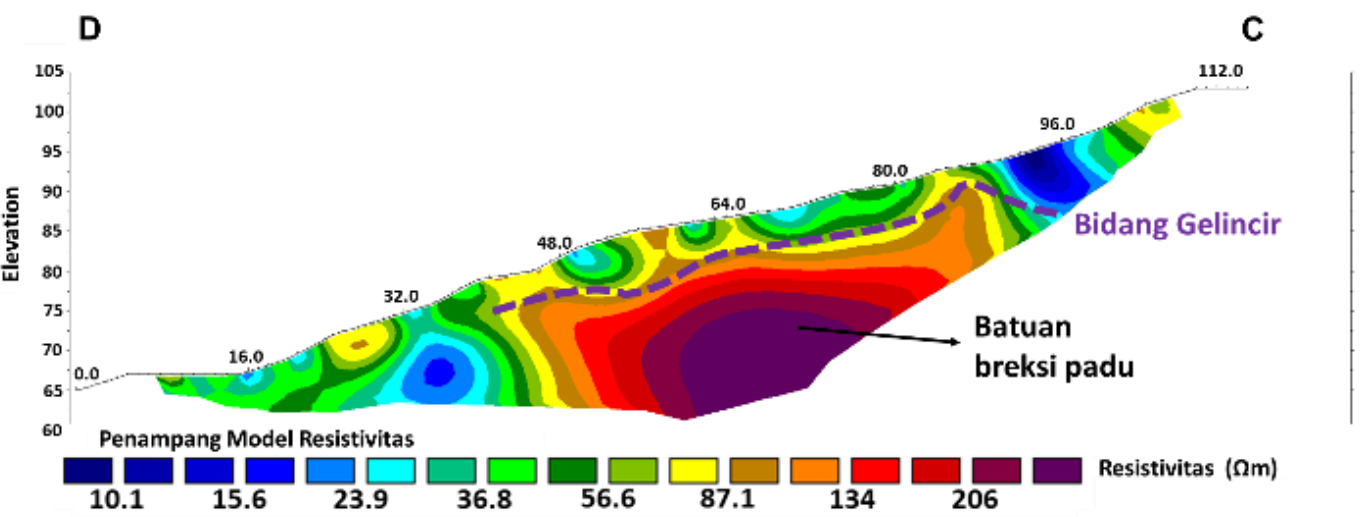

Gambar 7. Penampang CD hasil inversi dengan topografi.

Berdasarkan pengamatan di lapangan, dibagi menjadi tiga lapisan, yaitu yang berpola penampang yang dihasilkan dengan mengacu resistivitas rendah, menengah, dan tinggi pada tabel resistivitas batuan [17], serta peta (Tabel 1). geologi [9], batuan di daerah penelitian dapat 
Tabel 1. Interpretasi jenis batuan berdasarkan nilai resistivitas.

\begin{tabular}{|c|c|}
\hline $\begin{array}{c}\text { Resistivitas } \\
(\Omega \mathrm{m})\end{array}$ & Jenis Batuan \\
\hline $1-40$ & $\begin{array}{l}\text { Batuan berada pada permukaan } \\
\text { dengan nilai resistivitas relatif } \\
\text { rendah dan memiliki karakteristik } \\
\text { mudah mengalami longsoran. } \\
\text { Berdasarkan pengamatan lapangan } \\
\text { dan rentang resistivitas lapisan ini } \\
\text { terdiri dari tuf lempungan dan tuf } \\
\text { pasiran (sedimen tuf) dari Formasi } \\
\text { Tarahan yang berada pada } \\
\text { kedalaman 0,4-4 m. Lapisan ini } \\
\text { memiliki kandungan air yang tinggi. }\end{array}$ \\
\hline $40-120$ & $\begin{array}{l}\text { Diduga berupa lapisan kontak antara } \\
\text { batuan yang mengandung air di atas } \\
\text { dan batuan keras di bawah. Lapisan } \\
\text { ini terdapat pada kedalaman } \pm 2-4 \mathrm{~m} \\
\text { dan digunakan sebagai indikator } \\
\text { bidang gelincir. }\end{array}$ \\
\hline$>120$ & $\begin{array}{l}\text { Diduga berupa breksi padu dengan } \\
\text { komponen batuan beku dari Formasi } \\
\text { Tarahan pada kedalaman } 2-22 \mathrm{~m} \text {. }\end{array}$ \\
\hline
\end{tabular}

Berdasarkan tabel tersebut, lapisan dengan resistivitas $1-40 \Omega \mathrm{m}$ merupakan batuan yang berada di dekat permukaan (kedalaman antara 0,4-1,13 m pada penampang $\mathrm{AB}$ dan kedalaman antara $0,5-4 \mathrm{~m}$ untuk penampang $\mathrm{CD})$ dan memiliki karakteristik sangat mudah mengalami longsoran. Selain itu, lapisan dengan nilai resistivitas ini juga menunjukkan keberadaan batuan produk gunungapi yang diduga berupa tuf lempungan dan tuf pasiran (sedimen tuf) yang mengandung air dari Formasi Tarahan. Pada penampang CD terlihat litologi sedimen tuf ini cukup tebal pada kedalaman kurang dari $36 \mathrm{~m}$. Hal ini mungkin disebabkan oleh akumulasi longsoran-longsoran sebelumnya di bagian bawah lereng.

Dengan menggunakan asumsi bahwa model bumi sederhana dan implementasi parameter smoothness pada proses inversi, daerah dengan pola resistivitas menengah pada kedalaman \pm 2 m pada penampang $\mathrm{AB}$ dan \pm 4 m pada penampang $\mathrm{CD}$ ditunjukkan dengan resistivitas 40-120 $\Omega \mathrm{m}$ yang diduga berupa lapisan batas antara tuf di atas dan batuan keras di bawah. Nilai transisi ini dapat dijadikan sebagai indikator batas zona yang mungkin longsor atau biasa disebut sebagai bidang gelincir. Lapisan dengan resistivitas tinggi ditunjukkan dengan resistivitas yang bernilai $>120 \Omega \mathrm{m}$, diduga berupa breksi padu dengan komponen batuan beku dari Formasi Tarahan yang berada pada kedalaman 2-6 m untuk penampang $\mathrm{AB}$ dan 4-22 m untuk penampang CD.

Pada penampang $\mathrm{AB}$ juga dapat dilihat bahwa terdapat bentukan dengan nilai resistivitas tinggi muncul ke permukaan $(>120$ $\Omega \mathrm{m})$. Bentukan tersebut diduga merupakan bongkah batuan beku. Total penetrasi dari pemodelan inversi resistivitas pada lintasan pengukuran mencapai $6 \mathrm{~m}$ dengan iterasi 4 menghasilkan nilai root mean square error $11,4 \%$.

Berdasarkan penampang yang dihasilkan, litologi bawah permukaan daerah penelitian didominasi oleh batuan dengan nilai resistivitas sedang hingga tinggi yang diduga sebagai pasir lempungan. Lapisan batuan yang berada di permukaan diidentifikasi sebagai batuan lapuk yang dapat menjadi zona tersaturasi air. Volume sedimen tuf yang relatif kecil di bagian atas lereng tidak terlalu berdampak pada kerusakan yang tinggi tetapi memiliki risiko yang tinggi pada bagian bawah lintasan karena bersinggungan dengan jalan raya. Selain itu, keberadaan bongkah batuan beku di bagian atas lapisan pada penampang $\mathrm{AB}$ menjadi risiko tambahan ketika longsor karena dapat memperparah kerusakan yang dapat ditimbulkan.

Berdasarkan keadaan tersebut, dapat diambil kesimpulan bahwa daerah penelitian merupakan daerah rawan longsor. Hal ini dibuktikan dengan litologi bawah permukaan 
yang dominan dengan sedimen tuf dan pasir lempungan dengan kemiringan lereng $>30^{\circ}$.

\section{Analisis XRD}

Analisis XRD dilakukan pada satu sampel batuan yang diambil dari lapisan permukaan lereng yang mengalami longsoran pada elevasi 65 mdpl di lokasi pengukuran geolistrik lintasan CD (Gambar 8). Batuan tersebut secara makroskopis teridentifikasi sebagai tuf yang telah mengalami pelapukan cukup intensif. Tuf tersebut merupakan bagian dari penyusun Formasi Tarahan (Tpot) yang terbentuk pada umur sekitar PaleosenOligosen [5], bersamaan dengan pembentukan Formasi Sabu (Tpos) dan Formasi Campang (Tpoc).

Hasil analisis XRD (Gambar 9) menunjukkan bahwa tuf tersebut sangat kaya akan unsur dan senyawa silika oksida $\left(\mathrm{SiO}_{2}\right)$, besi oksida $\left(\mathrm{Fe}_{2} \mathrm{O}_{3}\right)$, alumunium oksida $\left(\mathrm{Al}_{2} \mathrm{O}_{3}\right)$, silika $(\mathrm{Si})$, kromium oksida $\left(\mathrm{Cr}_{2} \mathrm{O}_{3}\right)$, tembaga-besi oksida $\left(\mathrm{Cu}_{5} \mathrm{FeS}_{4}\right)$, kalsium karbonat $\left(\mathrm{CaCO}_{3}\right)$, dan natrium klorida $(\mathrm{NaCl})$. Kuarsa teridentifikasi sebagai mineral senyawa $\mathrm{SiO}_{2}$ yang berperan sebagai mineral penyusun utama tuf. Kandungan kuarsa yang relatif tinggi dan didukung oleh kehadiran unsur silika ( $\mathrm{Si}$ ) menjadi penguat ikatan antarsenyawa (welded). Selain itu, intensifnya proses pelapukan pada tuf tersebut juga tercermin dari cukup tingginya kehadiran mineral hematit $\left(\mathrm{Fe}_{2} \mathrm{O}_{3}\right)$. Tingkat oksidasi yang tinggi pada saat atau setelah pembentukan tuf tersebut menyebabkan mineral-mineral penyusunnya yang memiliki senyawa dengan ikatan oksida mengalami subtitusi dengan besi $\left(\mathrm{Fe}^{2+}\right)$.

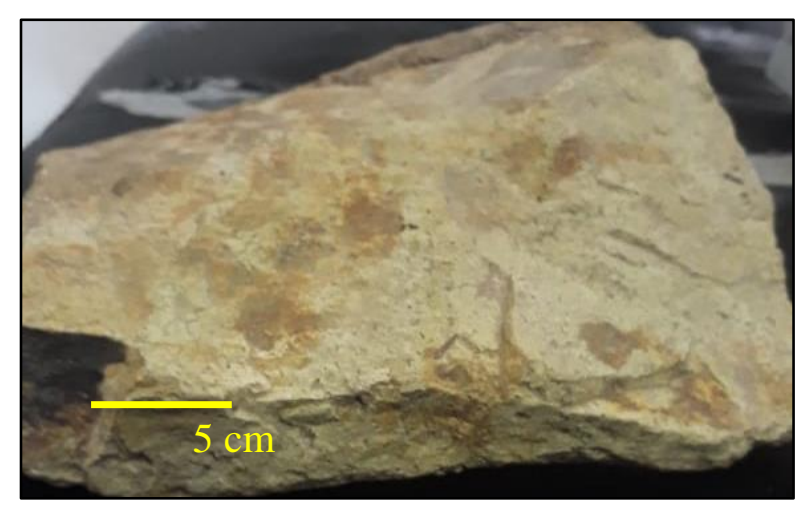

Gambar 8. Sampel batuan yang dianalisis XRD.

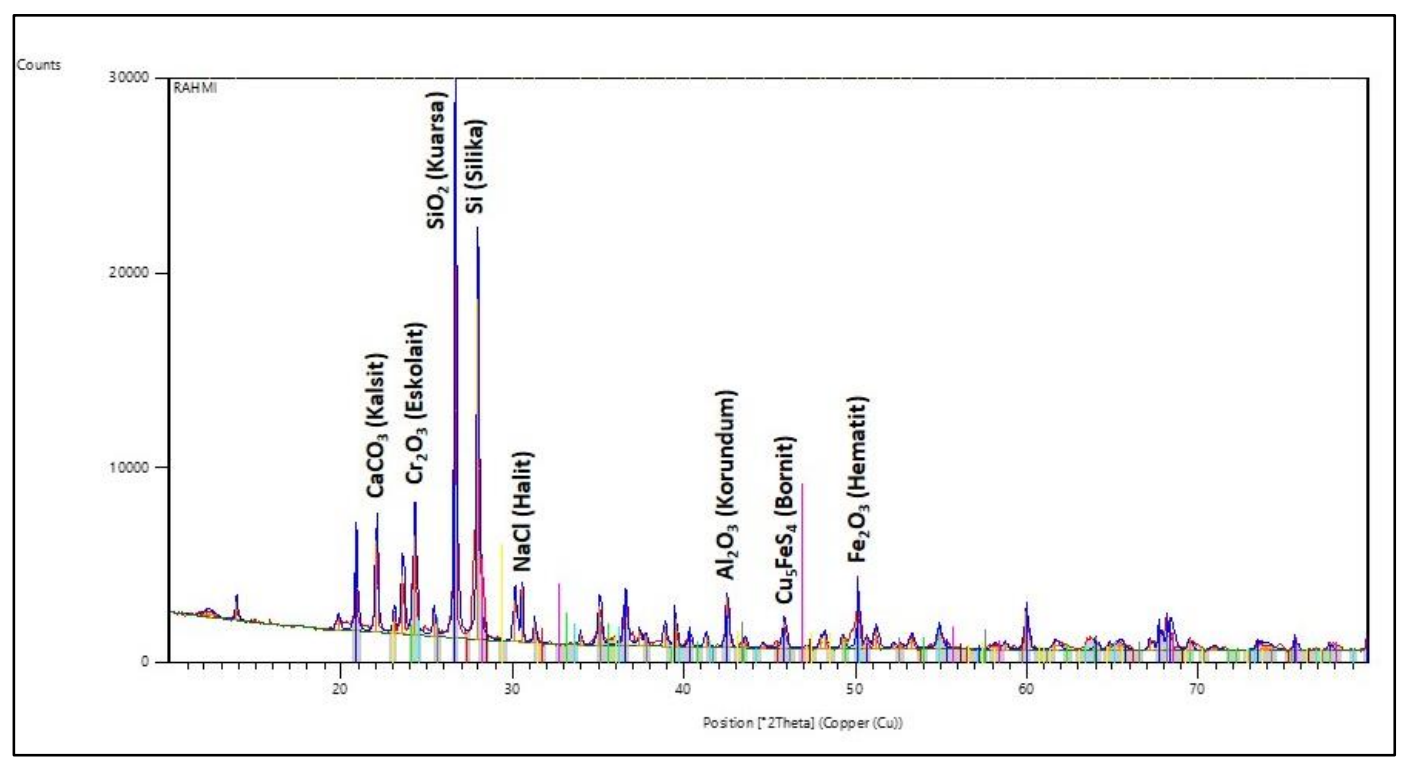

Gambar 9. Hasil analisis XRD. 
Tuf di daerah penelitian secara umum merupakan batuan yang sangat kompak dan masif karena tersusun oleh mineral-mineral yang relatif resisten dan didukung oleh ikatan antarbutirnya yang sangat kuat akibat terelaskan (welded). Pengurangan tingkat kekompakan disebabkan oleh proses oksidasi yang cukup intensif pada tuf tersebut.

Berdasarkan hal tersebut, hampir tidak mungkin terjadi pergerakan massa yang masif pada satu tubuh batuan tuf tersebut. Pergerakan massa pada tuf tersebut hanya dapat terjadi jika tuf tersebut telah mengalami pelapukan yang cukup intensif (menjadi sedimen tuf) dan terdapat litologi yang bisa berperan sebagai bidang gelincir yang melampar tepat pada batas bawah tuf tersebut. Indikasi-indikasi tersebut sesuai dengan hasil analisis geofisika yang menyebutkan bahwa terdapat lapisan bawah tuf yang dapat berperan sebagai bidang gelincir.

\section{Analisis Karakteristik Longsor}

Hasil pengamatan di lapangan menunjukkan bahwa jenis longsoran yang terjadi merupakan longsoran tanah dan batuan tipe translasi [1]. Berdasarkan analisis geolistrik, sedimen berbutir halus yang mengalami longsoran diperkirakan adalah sedimen tuf dan pasir lempungan. Berdasarkan analisis XRD, lapisan permukaan yang mengalami longsoran adalah tuf yang rentan mengalami longsoran karena kondisinya yang sudah teroksidasi dan mengalami pelapukan yang cukup intensif. Data yang diperoleh ini diharapkan dapat dimanfaatkan sebagai data dukung penataan wilayah berbasis potensi bencana.

\section{KESIMPULAN}

Litologi bawah permukaan dapat dibagi menjadi tiga lapisan berdasarkan nilai resistivitas, yaitu sedimen tuf dengan nilai resistivitas 1-40 $\Omega \mathrm{m}$ pada kedalaman 0,4-4 m, lapisan kontak atau kemungkinan bidang gelincir dengan nilai resistivitas 40-120 $\Omega \mathrm{m}$ pada kedalaman 2-4 m, serta breksi padu berkomponen batuan beku dengan nilai resistivitas $>120 \Omega \mathrm{m}$ pada kedalaman $2-22 \mathrm{~m}$. Litologi tuf rentan mengalami longsor karena kondisinya yang sudah teroksidasi dan mengalami pelapukan yang cukup intensif. Data yang diperoleh ini diharapkan dapat dimanfaatkan sebagai data dukung penataan wilayah berbasis potensi bencana.

\section{UCAPAN TERIMA KASIH}

Ucapan terima kasih Kami sampaikan kepada Fakultas Teknik Unila yang telah memberikan dana untuk kegiatan penelitian ini. Terima kasih juga Kami sampaikan kepada Pemerintah Daerah Kecamatan Panjang yang telah memberikan izin untuk penelitian ini.

\section{DAFTAR PUSTAKA}

[1] D. Karnawati, Gerakan Massa Tanah di Indonesia dan Upaya Penanggulangannya. Yogyakarta: Jurusan Teknik Geologi Fakultas Teknik Universitas Gadjah Mada, 2005.

[2] Misbahuddin, A. Husna, R. Toriq, dan A Marwanto, "Landslide Susceptibility Analysis Using Analitic Hierarchy Process in Sukatani and Its Surrounding, Purwakarta Regency, West Java", Jurnal Lingkungan dan Bencana Geologi, vol. 8, no. 1, pp. 19-30, 2017.

[3] T. S. Dewi, S. B. Kusumayudha, dan H. S. Purwanto, "Zonasi Rawan Bencana Tanah Longsor dengan Metode Analisis GIS: Studi Kasus Daerah Semono dan Sekitarnya, Kecamatan Bagelen, Kabupaten Purworejo, Jawa Tengah", Jurnal Mineral, Energi dan Lingkungan, vol. 1, no. 1, pp. 50-59, 2017, doi: 10.31315/jmel.v1i1.1773.

[4] R. Hidayat dan A. M. Zahro, "Identifikasi Curah Hujan Pemicu Longsor di Daerah Aliran Sungai (DAS) Serayu Hulu, Banjarnegara", in Prosiding Seminar Nasional Geografi UMS IX, pp. 41-50, 2018.

[5] V. G. M. Pangemanan, A. E. Turangan, dan O. B. A. Sompie, "Analisis Kestabilan Lereng dengan 
Metode Fellenius (Studi Kasus: Kawasan Citraland)", Jurnal Sipil Statik, vol. 2, no. 1, pp. 37-46, 2014.

[6] CNN Indonesia, "BNPB Ungkap Tren Peningkatan Bencana Banjir hingga Longsor", CNN Indonesia, 3 Februari 2021, [Online]. Tersedia:

https://www.cnnindonesia.com/nasional/2021020 2132713-20-601293/bnpb-ungkap-trenpeningkatan-bencana-banjir-hingga-longsor [Diakses: 27 Februari 2021].

[7] Badan Nasional Penanggulangan Bencana, Indeks Rawan Bencana Indonesia. Jakarta: BNPB, 2011

[8] Pemerintah Kota Bandar Lampung, "Sekilas Kota" [Online]. Tersedia: https://bandarlampungkota.go.id/sekilas-kota/ [Diakses: 16 Mei 2018].

[9] S. A. Mangga, Amirudin, T. Suwarti, S. Gafoer dan Sidarto, Peta Geologi Lembar Tanjungkarang, Sumatra. Bandung: Pusat Penelitian dan Pengembangan Geologi, 1993.

[10] R. Mulyasari, H. W. Utama, dan N. Haerudin, "Geomorphology Study on the Bandar Lampung Capital City for Recommendation of Development Area", in IOP Conf. Series: Earth and Environmental Science, vol. 279, no. 1, 2019, doi: 10.1088/1755-1315/279/1/012026.

[11] Pusat Vulkanologi dan Mitigasi Bencana Geologi (PVMBG), Wilayah Potensi Gerakan Tanah di Provinsi Lampung, Bandung, 2019.

[12] R. Mulyasari, N. Haerudin, Karyanto, I. G. B. Darmawan, dan Y. Arifianti, "Zonasi Area Potensi
Gerakan Massa di Sepanjang Sesar LampungPanjang Kota Bandar Lampung", Prosiding Semnas SINTA UNILA, Bandar Lampung, vol. 1, pp. 190-197, 2018.

[13] L. D. Wesley, Fundamentals of Soil Mechanics for Sedimentary and Residual Soils. New Jersey: John Wiley and Sons, 2009.

[14] ALOS Research and Application Project, "Peta DEM ALOS PALSAR". Tersedia: https://www.eorc.jaxa.jp/ALOS/en/index.htm [Diunduh: 20 Mei 2018].

[15] Badan Informasi Geospasial (BIG), "Peta Rupa Bumi Indonesia (RBI) digital, Skala 1:25.000". Tersedia: http://tanahair.indonesia.go.id/. [Diunduh: 20 Mei 2018].

[16] B. Hanafiah, A. D. Saputra, A. H. Pramana, F. Abdullah, M. Yanis, dan N. Ismail, "Identifikasi Struktur Berpotensi Longsor Berdasarkan Model Resistivitas Listrik 2D”, Prosiding Semirata 2017 Bidang MIPA BKS-PTN Wilayah Barat, Jambi, 2017.

[17] J. Utiya, As'ari, dan S. H. J. Tongkukut, "Metode Geolistrik Resistivitas Konfigurasi WennerSchlumberger dan Konfigurasi Dipole-Dipole untuk Identifikasi Patahan Manado di Kecamatan Paaldua Kota Manado", Jurnal Ilmiah Sains, vol. 15, no. 2, pp. 135-141, 2015, doi: 10.35799/jis.15.2.2015.10228.

[18] W. M. Telford, L. P. Geldart, dan R. E. Sherrif, Applied Geophysics. Cambridge: Cambridge University Press, 1990. 